\title{
Race, Paternalism, and Foreign Aid: Evidence from U.S. Public Opinion
}

\author{
ANDY BAKER University of Colorado at Boulder
}

$V$

irtually all previous studies of domestic economic redistribution find white Americans to be less enthusiastic about welfare for black recipients than for white recipients. When it comes to foreign aid and international redistribution across racial lines, I argue that prejudice manifests not in an uncharitable, resentful way but in a paternalistic way because intergroup contact is minimal and because of how the media portray black foreigners. Using two survey experiments, I show that white Americans are more favorable toward aid when cued to think of foreign poor of African descent than when cued to think of those of East European descent. This relationship is due not to the greater perceived need of black foreigners but to an underlying racial paternalism that sees them as lacking in human agency. The findings confirm accusations of aid skeptics and hold implications for understanding the roots of paternalistic practices in the foreign aid regime.

The African has largely remained a child type, with a child psychology and outlook. A child-like human cannot be a bad human, for are we not in spiritual matters bidden to be like unto little children ${ }^{1}$

-Jan Smuts, South African Prime Minister (1919-1924, 1939-1948)

$\mathbf{I}$ $\mathrm{n}$ recent years, a number of public intellectuals, politicians, and even pop culture icons have waged an increasingly visible debate on the merits of foreign aid. Aid advocates want to increase funding for development assistance in order to "make poverty history" (Sachs 2005), while aid critics bemoan wasted tax dollars and even counterproductive outcomes in the fight against underdevelopment. In the throes of the Great Aid Debate, contenders often levy accusations of racial prejudice, attributing problems in the aid regime to chauvinisms of varying kinds. Many aid proponents blame the purported shortfall in Western funding on racial resentment and, in particular, the alleged mass belief in donor countries that the nonwhite, foreign recipients of aid are undeserving (Sachs 2005). In contrast, aid skeptics claim that bloated donor commitments are driven by widespread racial paternalism, whereby recipients are seen as unable to develop with-

I am very grateful to Jennifer Fitzgerald, who offered many ideas over the course of this project, and also to David Bearce and Jennifer Wolak for reading multiple drafts. I also thank numerous others who gave me comments after a thorough read: Michael Barnett, Adam Berinsky, Corey Cook, John Griffin, Lisa Martin, Nathan Jensen, Lauren Prather, Paul Sniderman, Anand Sokhey, Joe Soss, Sven Steinmo, Irfan Nooruddin, Dustin Tingley, and the Institutions group of the University of Colorado at Boulder Institute for Behavioral Sciences (Lee Alston, Jennifer Bair, Carew Boulding, David Brown, Joseph Jupille, Celeste Montoya Kirk, Murat Iyigun, and Moonhawk Kim). David Cupery and James Pripusich provided valuable research assistance, and the Colorado European Center for Excellence provided some financial assistance. Special thanks to Nancy Thorwardson for doing the photoshopping. I am also grateful to Time-sharing Experiments in the Social Sciences (TESS) for funding the Knowledge Networks survey. All data, computer code, and the Online Appendix are available at http://spot.colorado.edu/ bakerab

Andy Baker is Associate Professor, Department of Political Science, University of Colorado at Boulder, Ketchum 106, 333 UCB, Boulder, CO 80309-0333 (Andy.Baker@Colorado.edu).

${ }^{1}$ Mamdani 1996, 4. out the assistance of white, Western providers (Easterly 2006; Moyo 2009).

These contradictory accusations touch on debates that exist within the literature on the psychology of racial prejudice, but ultimately neither side invokes empirical evidence to substantiate its allegations. Their charges thus raise important unanswered questions about the mass psychology of prejudice and redistributive policy preferences. Specifically, does prejudice, of either the paternalistic or resentment variety, shape the way people reason about foreign aid? Scholarship in mass political psychology, the sociology of race, and behavioral economics has produced no evidence regarding the directional impact, if any, of prejudice on mass attitudes toward government assistance for impoverished foreigners. More broadly, existing scholarship in political science cannot predict when mass publics will exhibit prejudice as paternalism toward an out-group and when they will exhibit prejudice as an uncharitable resentment. The aid skeptics' assertion that prejudice may manifest as a seemingly generous but ultimately dehumanizing paternalism, rather than a stingy resentfulness, has received scant attention among scholars of mass political psychology.

In this article, I analyze experimental data to examine the role that the race of recipients plays in donor countries' mass attitudes on foreign aid. I look at two different population-based survey experiments of U.S. citizens in which the race of exemplary aid recipients was manipulated randomly. Whereas virtually all previous studies of race and redistribution - almost all of them on the domestic welfare state - find white Americans to be less charitable in their policy preferences toward nonwhite recipients than toward white ones, these two experiments on foreign aid attitudes reveal the opposite: White Americans are more supportive of aid when cued to think of foreign poor of African descent (be they from Africa or the Caribbean) than when cued to think of foreign poor of white European descent. However, further analyses show that this is not a rare instance of unprejudiced generosity toward needy persons of color. The roots of this race-of-recipient effect, as revealed by analyses of mediating and moderating variables, lie not in estimations of recipients' 
material deprivation but in perceptions of the foreign poor's agency. Respondents think that white foreigners have a greater capacity for action than black foreigners, with the latter thus in need of paternalistic saving by the superior resources of the West.

This article makes contributions to scholarship on mass political psychology, especially that on racial prejudice, and to scholarship on foreign aid. It moves the literature on how the race of beneficiaries shapes mass support for redistribution into the international sphere. To date, research in political psychology and the sociology of race has overwhelmingly focused on the effects of racial bias on support for domestic government assistance programs (e.g., Feldman and Huddy 2005; Gilens 1999). Virtually all of their findings have supported the dominant resentment or conflict paradigm on the politics, economics, and sociology of intergroup redistribution, which holds that individuals are stingier and more vitriolic toward ethnic and racial others than toward fellow in-group members (Alesina, Baqir, and Easterly 1999). Because of these tendencies in the literature, an experimental study that manipulates the race of the foreign recipients of government assistance is long overdue and has an important theoretical payoff. By shifting the focus to a nondomestic recipient arena, I isolate the impact of racial prejudice when intergroup contact and competition are minimal and when the media narrative around the poor is one of inert victim instead of lazy spendthrift. Revealingly, I find that, in this context, prejudice manifests itself in paternalistic ways, not in uncharitable ways.

The empirical evidence also represents a contribution to a heated and high profile international debate about the nature of development assistance, as I find more support for the claims of aid skeptics than those of aid proponents. More narrowly, I also advance the theoretical literature on the causes of foreign aid attitudes. To date, research has largely pointed to citizens' foreign policy worldviews, political ideologies, or core values as the primary source of aid attitudes (Holsti 2004; Kinder and Kam 2009; Paxton and Knack 2012), yet these factors are potentially endogenous to important omitted variables if not to aid attitudes themselves. Efforts to identify exogenous influences have revealed a surprisingly short list that includes factors such as information levels (Gilens 2001) and who delivers aid (Milner and Tingley 2013a). I add race of recipient and paternalistic prejudices to this list. In doing so, this article also introduces new survey measures of perceived agency among the poor that subsequent scholars of poverty (both domestic and foreign) may find useful.

The article proceeds by first describing the uncharitable resentment paradigm that has dominated scholarly thought on the mass politics of redistribution across lines of ethnic and racial difference. It then lays out the paternalism alternative, generating some testable hypotheses in the process. The subsequent section describes the two population-based survey experiments along with estimated treatment effects and mediation analyses. Two final sections describe the article's implications for understandings of the modern foreign aid regime and for research on the political psychology of intergroup economic redistribution.

\section{RACE, REDISTRIBUTION, AND UNCHARITABLE RESENTMENT}

Prejudice-as-resentment has been the dominant framework in scholarly work on mass prejudice toward compatriot racial and ethnic out-groups. Allport's classic study of racial prejudice defined prejudice as "an antipathy based upon a faulty and inflexible generalization... toward a group as a whole, or toward an individual because he is a member of that group" ([1954] $1979,9)$. In keeping with this perspective, the vast majority of studies on intergroup relations in racially heterogeneous societies center on overt resentment or conflict (Jackman 1994, 56). For example, a large literature subsequent to Allport on the U.S. and other cases documents various forms of antipathy toward racial and ethnic out-groups (e.g., Gilliam and Iyengar 2000; Brader, Valentino, and Suhay 2008; Aguilar et al. 2014; Zucco 2014).

This prejudice-as-resentment paradigm has significantly shaped research on how race perceptions relate to mass attitudes toward government redistribution within diverse societies. It paints racial attitudes as carrying a heavy dose of "uncharitable resentment." Because resentment across racial lines is strong, groups - and especially economically dominant ones-oppose expansive government efforts to redistribute and to provide public goods (Griffin and Newman 2008), and conservative politicians need only "race code" their framings of redistributive policy to stoke opposition (Gilens 1996a; Mendelberg 2001). Cross-nationally, the correlation between racial diversity and the extent of government redistribution is negative and strong, with some concluding that diversity is what makes the U.S. welfare state thinner than most European ones (Alesina, Glaeser, and Sacerdote 2001). The negative correlation between cultural heterogeneity and public goods provision is also a strong one, with some scholars calling it "one of the most powerful hypotheses in political economy" (Banerjee, Iyer, and Somanathan 2005, 639). To be sure, not all scholars attribute this effect to out-group resentment (Habyarimana et al. 2009), but an enormous body of research on individual-level attitudes does confirm the uncharitable resentment hypothesis that individuals are less willing to have their tax contributions redistributed to racial out-group members than to in-group members. Evidence abounds, especially for the U.S. setting, in both observational (Hancock 2004; Kinder and Sanders 1996; Winter 2008) and experimental studies (Feldman and Huddy 2005; Gaertner and Dovidio 1986; Gilens 1996a; Kinder and Kam 2009; Mendelberg 2001).

To date, there has been little direct research on whether racial prejudice drives development assistance policy or mass attitudes about foreign aid in donor countries, but some scholars working on foreign aid have made ready use of the prevailing uncharitable 
resentment paradigm. Most notably, the aid activist community's leading intellectual, Jeffrey Sachs, attributes what he sees as a shortfall in aid funding to "an amazing reservoir of deep prejudices" toward Africans that has "become accepted as truths by the broad public" (Sachs 2005, 310, 309). Sachs sarcastically mimics this alleged "conventional rich-world wisdom about Africa" with the following:

... if we actually gave [Africa more] aid, where would it go? Right down the drain, if the past is any guide. ... Africa is corrupt and riddled with authoritarianism. It lacks modern values and the institutions of a free market economy needed to achieve success. In fact, Africa's morals are so broken down that it is no surprise AIDS has run out of control (page 309).

More directly, Kinder and Kam (2009) find, in line with the uncharitable resentment model, that ethnocentric Americans are less supportive of foreign aid than nonethnocentric ones. Their analysis seems to imply that white Americans would be stingier toward black foreigners than toward white ones, although they fall short of explicitly making or testing such a claim. ${ }^{2}$ All told, scholarly thinking on redistribution across racial lines is grounded in presumptions of mass resentment and miserliness.

\section{RACE, REDISTRIBUTION, AND PATERNALISM}

Sachs's intellectual archrival, William Easterly, sees racial prejudice to be operating in a completely different way in the modern foreign aid regime. The title of his 2006 book, a locus classicus of aid skepticism, is The White Man's Burden, which itself evokes Kipling's classic caricature of the racial paternalism behind U.S. imperialism in the late 19th century. In it, Easterly asserts the following: "The most infuriating thing ... is how patronizing they are (usually unconsciously). Here's a secret: anytime you hear a Western politician or activist say 'we,' they mean 'we whites'-today's version of the White Man's Burden" (p. 26). Many aid skeptics besides Easterly, including some African intellectuals, also chafe at the paternalistic sentiment that the West is needed to "save" or "fix" Africa (Moyo 2009; Wainaina 2005), a sentiment exemplified by rock star and aid activist Bono's charge that the end of poverty is "up to us" in the West (Sachs 2005: xviii).

\section{Paternalistic Stereotyping}

With its root word from the Latin for "fatherly" ( $p a-$ ternus), the term "paternalism" evokes the authoritative supervision of a parent-child relationship. More

\footnotetext{
${ }^{2}$ Bermeo and Leblang (forthcoming) find indirect evidence of ingroup favoritism, although not necessarily out-group resentment, in aid attitudes: They show that the number of immigrants from recipient country $X$ that live in donor country $Y$ is positively correlated with $Y$ 's aid volumes to $X$. This relationship is due in part, they claim, to immigrants pressuring their host country governments on behalf of their home country. (See also Barnett 2011,230.)
}

formally, paternalism is the notion that the actions or preferences of certain persons require interference from others, on the basis that such persons cannot be trusted to do right by themselves or others if left to their own devices (VanDeVeer 1986, 12). In turn, racial paternalism is a person's belief that, to be protected from its own lax moral discipline or inability to act, a particular race of people is in need of such interference from one's inherently superior in-group.

In leveling the accusation of racial paternalism, Easterly and other aid skeptics are implicitly recognizing that stereotypes and prejudice toward out-groups come in more than one form. The uncharitable resentment paradigm has taken a cue from Allport by defining prejudice strictly as contempt or antipathy, but recent research on out-group perception shows that multiple dimensions are needed to fully classify the content of various stereotypes (Fiske, Cuddy, and Glick 2007; Gray, Gray, and Wegner 2007). Whereas sympathy or antipathy toward a group largely depends on its perceived intentions, agency perception, meaning judgments about the group's ability to act on its intentions, is a dimension that is orthogonal to the standard sympathy-antipathy continuum (Gray et al.2011). Stated differently, it is not simply the case that people admire competent out-groups and feel contempt toward incompetent ones (Jackman 1994). Instead, stereotypes can be mixed (Katz and Hass 1988). People can dislike groups they stereotype as highly competent in their actions, as exemplified by the fact that many anti-Semites think Jews are good at business (Berinsky and Mendelberg 2005). Or people can feel warmly toward groups they assume to be lacking in a capacity to act, such as the elderly, the mentally disabled, and, of course, children. This latter combination of perceived group traits - inert while not having mal-intentionscorresponds to paternalistic stereotypes and feelings of pity (Fiske et al. 2002; Weiner 1993). For holders of paternalistic stereotypes, their prejudice lies not in contempt or a resultant withholding of charity but in the underestimation of agency.

I hypothesize that whites in a wealthy country like the United States attribute less agency-and thus a greater need for paternalistic rescuing by foreign aidto poor black foreigners than to poor white foreigners with equivalent material needs. Paternalism by whites toward Africans has a long history. Philosopher Georg Hegel referred to Africa as the "land of childhood" (Hegel [1837] 2007, 91), Albert Schweitzer wrote of Africans that the "negro is a child" (Joy 1947, 185), and paternalistic considerations were long used by Europeans to justify colonialism and by Americans to justify slavery (Genovese 1974). (See also the epigraph.) But what might be its psychological roots in mass publics in the contemporary Western world?

Research on mind perception has revealed a tendency for people to "infrahumanize" or "dementalize" out-groups, meaning that, in reasoning about the minds of othered persons, individuals deny them certain distinctively human traits. Typically, this exhibits as a subtle tendency to overlook or minimize an outgroup's ability to carry distinctly human emotions (e.g., 
disappointment or remorse) or capacities, such as the ability to develop a plan and act out its intentions (Leyens et al 2000; Kozak, Marsh, and Wegner 2006). At its most extreme, infrahumanization can manifest as the complete denial of mind and humanity, as exemplified by the Rwandan genocide perpetrators' use of the term "cockroaches" for the Tutsi minority. The extent of infrahumanization thus falls on a continuum, ranging from perception of full human mind to perception of no human mind, depending on the perceiver and-more importantly for present purposesthe perceived (Waytz et al. 2010). I expect U.S. whites to more severely underestimate the agentic capacities of foreign blacks - their racial out-group - than those of foreign whites - their racial in-group. To be sure, foreign whites are an out-group of sorts in this scenario because of their foreignness, but they are less different than foreigners of African descent.

Western mass media portrayals and popular narratives around black-majority countries reinforce this propensity because they stress helplessness and victimization. In the U.S. and other Western nations, major media outlets cover little about African and Caribbean countries except their violent conflicts, natural disasters, and heavy disease burdens (Fair 1993; Hawk 1992; Mamdani 2009; Seay 2012; Wainaina 2005). ${ }^{3}$ In doing so, Western media "dehumanize Africans," and "the specificity of African experiences and actions is lost" (Fair 1993, 11; Seay 2012). Rich-country citizens learn to overlook the potential for agency by the black foreign poor (van Heerde and Hudson 2010), and the lack of contact exacerbates the ignorance of Africans' agentic capacities (Malle and Pearce 2001). Marketing efforts to raise private donations may also contribute: “... some well-intentioned Western antipoverty campaigns may be inadvertently reinforcing troubling stereotypes, for instance by downplaying the agency of Africans themselves while emphasizing the role of outside actors" (Brainard and LaFleur 2008, 23). All told, because of this dominant media narrative, Americans view foreigners of African descent as largely ill-defined, faceless objects of pity that, in paternalistic fashion, can be "saved" only by the superior resources of the U.S. and the rest of the developed world. The foreign poor of African descent are not blamed for their plight, but they are also not expected to be able to do anything about it in lieu of outsider help.

Because they view the foreign poor of African descent with such paternalistic lenses, the generosity of donor country citizens will be conditioned by the form in which aid is delivered. Few government redistribution programs simply grant no-strings-attached cash benefits to recipients, in part because paternalistic interventions make the costs of redistribution more palatable to those who see themselves as net contributors. The form of paternalistic interference in welfare

\footnotetext{
${ }^{3}$ Academic studies and commentary on this are legion, but perhaps the best summary of the phenomenon appeared in a headline in the parodic newspaper The Onion, "Tens of Thousands Dead in Ongoing Africa." May 17, 2012, p. 1.
}

states, charitable giving, and development assistance can be coercive, whereby the paternalistic interference restricts the recipient's behavioral choice set (e.g., requiring individuals to change their lifestyles or countries their policies) via enforcement by the donor or a third party (Soss, Fording, and Schram 2011). Alternatively, it can be subtle, whereby the paternalistic interference restricts the recipient's choice set via the mode of delivery, as exemplified by the provision of food stamps instead of cash (Thaler and Sunstein 2008). Finally, paternalistic interference can be minimal, lying merely in the giving of aid itself: unconditional cash transfers, which do not restrict a recipient's behavioral choice set, are perhaps the sole example. Because whites underestimate the agentic capacity and competence of the black foreign poor, they should recoil from unconditional cash donations, instead extending their pity and generosity to foreign blacks only when there is some degree of paternalistic control over what recipients can do with the funds. Again, the analogy to children is pertinent: parents extend paternalistic care to children in the form of advice, persuasion, conditionalities, and coercion, yet few entrust children to make future-oriented, self-improving decisions with the family's money.

Why do U.S. whites not apply this more benevolent, albeit still prejudicial, stereotype and charity to compatriots of African descent? ${ }^{4}$ Social cognitive research suggests that hostile stereotypes exist in the presence of perceived competition and threat: "paternalistic stereotypes portray out-groups that are neither inclined nor capable to harm members of the in-group" (Fiske et al. 2002, 879, emphasis in the original; see also Cottrell and Neuberg 2005). With African-Americans seen to be competing directly with them for precious fiscal resources and jobs, American whites impute to AfricanAmericans bad intentions and, as a result, less charitable stereotypes. In reinforcement of this in the U.S. context, media content tends to present domestic poverty as a "black problem," with African-Americans showing up disproportionately as the subjects of media stories on poverty (Gilens 1996b). Many media and elite characterizations of the nonwhite domestic poor primarily depict individual-level, rather than structural, causes of poverty: from having too many children to spending money on frivolous things to not participating in job training programs (Clawson and Trice 2000; Iyengar 1990). Similarly, many whites in the U.S. adhere to the belief that institutional contexts for economic activity and opportunity are equivalent for domestic whites and domestic blacks (Hartz 1955): "With new rights now established [in the 1960s], white Americans increasingly concluded that equal opportunity had been achieved and, thus, poor minorities must be responsible for their

\footnotetext{
${ }^{4}$ Admittedly, these constructs about persons of African descent are not entirely absent from the U.S. domestic context. Daryl Scott documents a long-running "popular image of blacks as a pathological underclass" deserving not of contempt but of pity (Scott 1997, 200). As mentioned above, however, empirical research on mass attitudes about race and redistribution still show sentiments of uncharitable resentment, rather than charitable pity, to dominate among American whites.
} 
own poverty" (Soss, Fording, and Schram 2011, 61). The consequences of all these tendencies are evident in public opinion data: in a 2008 survey, $60 \%$ of white Americans agreed that, if blacks would only try harder, they could be just as well off as whites. ${ }^{5}$ By contrast, just $20 \%$ of white Americans in 2011 agreed that, if people in poor countries would only try harder, they could be just as well off as those in the United States. ${ }^{6}$

\section{Hypotheses}

I expect to find that U.S. whites' attitudes about international redistribution across racial lines will be shaped not by uncharitable resentment but by a more charitable but also racially prejudiced paternalism. To test this theoretical proposition, I take a cue from some of the research designs used in studies of race and the welfare state in the U.S. context, harnessing survey experiments that manipulate the race of exemplary recipients of foreign aid to gauge the impact of race on white Americans' attitudes toward development assistance. I hypothesize that respondents will be more supportive of foreign aid when cued to consider foreign poor of African descent than when cued to consider foreign poor of European descent. On its own, however, finding a race-of-recipient effect in this direction would not confirm the presence of racial paternalism, so I pose and test two further hypotheses. First, I hypothesize that the source of the greater generosity toward those of African descent will be not a perceived deficit in their material welfare but rather a perceived deficit in their capacity to take action to improve their own material welfare. In other words, I expect to find that the effect of race-of-recipient on American whites' foreign aid attitudes will be mediated by their perceptions of agency among the foreign poor (and not by their perceptions of material deprivation among the foreign poor). Second, I expect to find that the impact of race-of-recipient on American whites' foreign aid attitudes will be sensitive to the form by which paternalistic interference is applied in aid delivery. Specifically, American whites will be more generous about foreign aid to those of African descent only when they see the assistance as being delivered with coercive or subtle paternalistic strings attached. They will not feel more generous to those of African descent when the poor recipients of aid are seen to have freedom to spend the funds how they please (e.g., unrestricted cash grants). Stated differently, I expect that the degree of donor control over how aid is used by the poor will moderate the race-ofrecipient effect.

\section{TWO RACE-OF-RECIPIENT EXPERIMENTS}

To test these hypotheses, I designed two populationbased, internet survey experiments of U.S. citizens. Sampling techniques, response rates, randomization

\footnotetext{
5 American National Election Studies 2008. See Online Appendix for wording to Black resentment item.

${ }^{6}$ This finding is from the CM experiment survey data discussed below. See Online Appendix for wording to Resentment of the foreign poor $1(\mathrm{CM})$
}

checks, descriptive statistics, and full wordings of experimental treatments (with their accompanying photographs) and post-treatment measures are shown in the Online Appendix.

\section{Experimental Design}

Both experiments have fully crossed factorial designs with race (black or white) of exemplary foreign aid recipients as one factor and, to see if it moderates any race-of-recipient effect, the form of paternalistic interference in aid delivery as the other. The first experiment, conducted by Knowledge Networks in April and May 2011 ( $N=2,031$ non-Latino whites), had a $2 \times 3$ factorial design plus a control for a total of 7 experimental groups. The race manipulation was established by reporting exemplary beneficiaries of aid as being either from the African country of Cameroon or the East European nation of Moldova. The other, form-of-paternalism dimension had the following three manipulations: one for coercive paternalism with a positive valence, one for coercive paternalism with a negative valence, and one in which the precise nature of aid delivery was left unspecified. Throughout, this is referred to as the "CM experiment."7

The second experiment, conducted by the Cooperative Congressional Election Study (CCES $)^{8}$ in October of $2012(N=1,000),{ }^{9}$ had a $2 \times 2$ factorial design in which the race-of-recipient manipulation occurred by randomly assigning the exemplary beneficiaries of aid to be either from the East European nation of Armenia or the Caribbean nation of Guyana. ${ }^{10}$ On the other dimension, the form of paternalistic interference was specified by describing the aid as either unconditional cash payments or in-kind goods and services (henceforth "AG experiment"). Figure 1 shows the structure of the two experiments.

The experimental manipulations occurred via subtle changes to an opening photo and to wordings in a short opening text just underneath it. Race was indicated not by explicit textual reference but by showing a photograph of either a white or black family and by reference to the family in the text as "a poor [Cameroonian/Moldovan/Armenian/Guyanese] family." In each of the two experiments, the picture for one race treatment was photoshopped so that only family members'

\footnotetext{
7 The experimental treatments in the CM survey were administered according to a randomized block design with the seven-point ideology scale (which runs from extreme liberal to extreme conservative) as the blocking variable. Randomization of treatments within the categories of a relevant covariate can dramatically boost statistical efficiency (Imai, King, and Stuart 2008).

${ }^{8}$ Andy Baker, P.I. Cooperative Congressional Election Study, 2012 Colorado Content. University of Colorado at Boulder. http://cces. gov.harvard.edu. For a demonstration of the high validity of the CCES sampling approach relative to more traditional sampling techniques, see Ansolabehere and Rivers (2013).

${ }^{9}$ For the $\mathrm{CM}$ experiment, African-Americans were included in the sampling frame (by necessity) but are dropped from the analyses below, except where indicated.

${ }^{10}$ In both experiments, respondents were told in the opening text what world region (Africa, Caribbean, or Eastern Europe) their exemplary country lies in.
} 


\section{FIGURE 1. Design of Two Experiments}

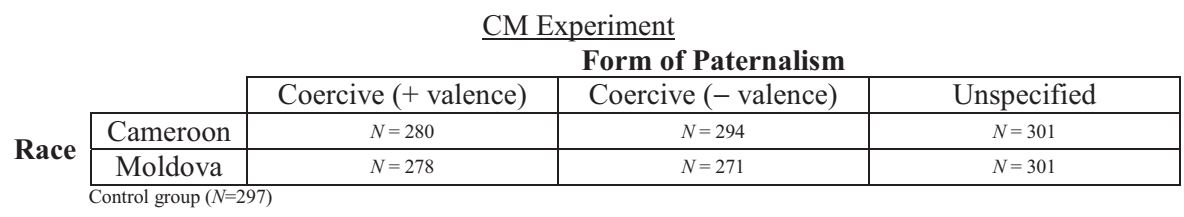

AG Experiment

Form of Paternalism

\begin{tabular}{|c|c|c|c|}
\hline & & & \\
\hline & Unconditional cash & In-kind \\
\hline \multirow{2}{*}{ Race } & Armenia & $N=224$ & $N=222$ \\
\hline & Guyana & $N=210$ & $N=220$ \\
\hline
\end{tabular}

heads and skin color differed from those in the photo for the other race treatment. Clothing, family size, childrens' ages and genders, and housing background were thus the same for all respondents (Mutz 2011, 62-3). ${ }^{11}$ The control group in the CM experiment saw no photo or country name.

These four countries and their pairings were chosen for several reasons. A primary concern was to limit the extent to which resulting differences in respondents' foreign aid beliefs could be attributed to actual differences in poverty levels between the two groups. After all, the goal is to isolate the impact of racial stereotypes net of aid recipients' objective material need. Thus, the country pairings (Cameroon/Moldova and Armenia/Guyana) were established so that the national average incomes were roughly equivalent across the two race treatments. For example, Moldova is the poorest white-majority country in the world, and Cameroon has roughly the same GNI per capita. ${ }^{12}$ In the opening text to the $\mathrm{CM}$ experiment, respondents were thus (truthfully) informed that, in the exemplary country, "the average person survives on the U.S. equivalent of $\$ 5$ per day. (That would be like living on $\$ 1,800$ per year in the U.S.)"13 (That said, questions on perceived material need were also included among the post-treatment measures and are introduced as statis-

\footnotetext{
${ }^{11}$ In the CM experiment it was the white family's photograph that was doctored (i.e., the black family photograph was an original pulled from the internet), whereas in the AG experiment it was the black family's photograph that was doctored. This alternation was done to guard against the potential charge that subconscious recognition of the photoshopping could be driving the observed race-of-recipient effect.

12 Also, the ability to equilibrate average country-level incomes between country pairs is why this design is the best way to minimize objective differences in well-being when comparing foreign blacks and foreign whites. The alternative of holding country context constant by using as treatments white and black families from within a single less developed country (e.g., Botswana, South Africa, or Zimbabwe) poses a serious problem. Even if I had described the black and white families as having equal incomes, the real world gaps between whites and blacks in these countries are far greater than those between any of the chosen country pairs and between Africa/the Caribbean and the East European periphery. The GNIs per capita in the four countries in 2009 were as follows: Cameroon $\$ 915$, Moldova \$968, Armenia \$3,180, Guyana \$2,540 (http://data. worldbank.org/data-catalog/world-development-indicators).

${ }^{13}$ Because they are wealthier, the numbers were $\$ 7$ and $\$ 2,500$, respectively, in the AG experiment.
}

tical controls in the mediation analyses reported below.) Countries were also well-matched by pairs on the amount of aid each received as a share of its GDP, and this share was conveyed to respondents. Moreover, there is little knowledge or news coverage in the U.S. about these four countries, so it is highly unlikely that specific information about politics or economics in any of them is driving treatment effects. ${ }^{14}$ Finally, for the African-descent treatments in the two experiments, countries from two different world regions, Africa and the Caribbean, were chosen to try to determine the impact of racial stereotypes above and beyond the effect of continental ones.

The nature and severity of paternalistic interference were experimentally manipulated in the following ways. In the CM experiment, three different treatments explored the impact of coercive forms of paternalism while balancing the coercive manipulation for valence. To provide a baseline for comparison, the form of paternalism was left unspecified for one group: "the aid money is often used by poor families like the one pictured above." By contrast, respondents in the other two groups read an extra sentence and saw an extra person in their photos, both of which evoked forms of coercive paternalism. For those in the positive valence group, the sentence read, "an American aid expert is often on hand to tell the poor how to use the aid to improve their lives," and the photo had a friendly white man with a clipboard alongside the family. Respondents in the negative valence group read a sentence that said "an American aid expert is often on hand to instruct but sometimes limits the choices that the poor recipients of aid can make." This message was reinforced with a stern-looking white man standing next to the family. In the AG experiment, the manipulation for the two groups was strictly textual, and here milder forms of paternalism were explored. The unconditional cash manipulation was a sentence at the end of the opening text that said "the families often receive the aid as cash so that they can spend it any way they would like." For the other group, I invoked a subtle form of paternalism by describing aid as an in-kind transfer: "the families

\footnotetext{
${ }^{14}$ This is the primary reason why little-known Guyana (whose African-descent population is around $30-40 \%$ ) was chosen as the Caribbean nation over better-known black-majority countries like Haiti and Jamaica.
} 
often receive the aid as particular goods and services, such as free school materials or free doctors' visits."

In each survey, the experimentally manipulated opening text and photo were followed by about a dozen post-treatment measures: questions intended to gauge potential mediators and the dependent variable. To measure the dependent variable of interest, public opinion about foreign development assistance, I created an Index of support for foreign aid that is the shared variation among three variables. ${ }^{15}$ The first is Preferred aid amount per American and gauges how much per American per year the respondent thinks the U.S. government should devote to foreign aid. Respondents chose dollar figure ranges (e.g., \$20-39) arrayed on a seven-point ordinal scale (which was recoded to each category's dollar-amount midpoint) after being told that the actual average is $\$ 40$. The second is $U . S$. has moral obligation to aid, a five-category variable that gauges agreement with the following statement: "The U.S. has a moral obligation to help foreign poor countries." The third is Preferred aid amount in the exemplary country, a seven-category variable that measures whether respondents believed aid should increase (and by how much), decrease (and by how much), or stay the same in the country of their treatment group. The index is the scores generated by the first component from a principal components analysis calculated on the three variables. ${ }^{16}$ The dependent variable is coded as a $z$ score, so all reported results are expressed in standard deviation units.

\section{Treatment Effects}

Table 1 reports estimated treatment effects-both main effects and interaction effects - for all the experimental conditions in both experiments. Figure 2 shows point estimates and confidence intervals for the primary experimental conditions of interest. Results of difference of means tests among various combinations of experimental groups are reported where relevant in the text.

In contrast to most previous studies' findings on race and the American welfare state, I find that, with just one exception, respondents were more supportive of aid when primed to think about it going toward recipients of African descent than when they thought about it going to recipients of European descent. For the CM experiment, the main effect of the Cameroonian treatment relative to the control group is shaded in grey in Table 1: respondents primed to think about Cameroonians were more enthusiastic about aid than were those primed to think about Moldovans $(t=$ $.179, p=.000)$. Figure 2 also depicts the differences in support for foreign aid between respondents in these

\footnotetext{
${ }^{15}$ Following the advice of Mutz (2011, 100, 123-6), who says there's "no excuse" for single variable indicators in the context of a population-based survey because one need not waste valuable questionnaire space on measuring potential confounds, I use indices to measure all key concepts.

16 The three items have a Cronbach's alpha of .87 in the CM experiment survey and .85 in the AG experiment survey.
}

two groups. The main effect of the Cameroonian treatment was also statistically significant relative to the control group $(t=.230, p=.002)$, whereas the effect of the Moldovan treatment relative to control was not statistically distinguishable from zero $(t=.051$, $p=.495) .{ }^{17}$

The average effect across the three Cameroonian treatment groups relative to that across the three Moldovan groups was about one-fifth of a standard deviation, which can be expressed more intuitively as actual aid dollars given the wording of one of the questions in the dependent variable index. One-fifth of a standard deviation on the preferred aid amount per American variable equates to about $\$ 4.50$, or about $11 \%$ of per person annual aid outflows. The average respondent wanted to cut U.S. aid from its current per person level by $\$ 11$, which can be derived by comparing the observed mean on this variable (\$29) to the actual government figure (\$40) of which they were told in the question wording. As a result, a typical respondent in a Moldovan treatment group wanted to cut U.S. aid by $40 \%$ more than one in a Cameroonian treatment group, a sizeable substantive effect.

In the AG experiment, respondents in the Africandescent (Guyana) treatment group were also more supportive of foreign aid than those in a European-descent (Armenian) group, but only when the aid was described as being delivered with a subtle dose of paternalism. When recipients were described as receiving unconditional cash payments, the effect of race disappeared. Here, the most relevant treatment effect (shaded in grey in Table 1) is the effect of race within the in-kind treatment condition: a yawning race gap of a quarter standard deviation (equivalent to $\$ 5.50$ in per-person annual aid outflows) exists when recipients were described as having their hands tied via delivery of actual goods and services instead of cash $(t=.259, p=.000$; see also Figure 2). In contrast, no such race gap exists when recipients were described as receiving unconditional cash payments, as evidenced by the virtually equivalent means and confidence intervals in the two rightmost entries of Figure 2.

In sum, respondents are generally inclined to be more supportive of foreign aid when thinking about poor black recipients than when thinking about white ones, ${ }^{18}$ but this apparent generosity toward those of African descent is turned off when the specter of their having full control over how to use aid funds is raised. In other words, despite their greater generosity toward the black poor, respondents' attitudes about foreign aid are sensitive to the form of paternalistic control only when they are thinking about black recipients, not when they are thinking about white recipients. This

\footnotetext{
17 The impacts of race within each of the three forms of paternalism treatment groups were statistically equivalent in size, which was as expected given that none of the treatments on this dimension explicitly referenced unconditional cash handouts.

${ }^{18}$ In the Online Appendix, I show that these treatment effects do not exhibit a lot of heterogeneity across important subgroups.
} 


\begin{tabular}{|c|c|c|c|c|c|}
\hline \multicolumn{3}{|c|}{ CM EXPERIMENT $(N=2,022)$} & \multicolumn{3}{|c|}{ AG EXPERIMENT $(N=876)$} \\
\hline Experimental condition & $\begin{array}{l}\text { Main } \\
\text { effects }\end{array}$ & $\begin{array}{l}\text { Interaction } \\
\text { effects }\end{array}$ & $\begin{array}{l}\text { Experimental } \\
\text { condition }\end{array}$ & $\begin{array}{l}\text { Main } \\
\text { effects }\end{array}$ & $\begin{array}{l}\text { Interaction } \\
\text { effects }\end{array}$ \\
\hline Cameroon & $\begin{array}{l}.179^{* * *} \\
(.048)\end{array}$ & & Guyana & $\begin{array}{l}.115^{*} \\
(.066)\end{array}$ & \\
\hline Moldova & $\begin{array}{l}\text { Baseline } \\
\text { category }\end{array}$ & & Unconditional cash & $\begin{array}{l}-.160^{* *} \\
(.066)\end{array}$ & \\
\hline Control group & $\begin{array}{l}-.051 \\
(.075)\end{array}$ & & Armenia & Baseline category & \\
\hline Coercive paternalism (+) & $\begin{array}{l}-.047 \\
(.059)\end{array}$ & & In-kind & Baseline category & \\
\hline Coercive paternalism (-) & $\begin{array}{c}-.160^{* *} \\
(.058)\end{array}$ & & & & \\
\hline Unspecified & $\begin{array}{l}\text { Baseline } \\
\text { category }\end{array}$ & & & & \\
\hline Cameroon $\times$ unspecified form & & $\begin{array}{l}.208^{* *} \\
(.081)\end{array}$ & Guyana $\times$ in-kind & & $\begin{array}{l}.259^{* * *} \\
(.092)\end{array}$ \\
\hline Moldova $\times$ unspecified form & & $\begin{array}{l}\text { Baseline } \\
\text { category }\end{array}$ & Armenia $\times$ in-kind & & $\begin{array}{l}\text { Baseline } \\
\text { category }\end{array}$ \\
\hline Cameroon $\times$ coercive paternalism $(+)$ & & $\begin{array}{l}.137^{*} \\
(.083)\end{array}$ & $\begin{array}{l}\text { Guyana } \times \\
\text { unconditional cash }\end{array}$ & & $\begin{array}{l}-.043 \\
(.092)\end{array}$ \\
\hline Moldova $\times$ coercive paternalism $(+)$ & & $\begin{array}{l}-.023 \\
(.083)\end{array}$ & $\begin{array}{l}\text { Armenia } \times \\
\text { unconditional cash }\end{array}$ & & $\begin{array}{l}-.009 \\
(.094)\end{array}$ \\
\hline Cameroon $\times$ coercive paternalism $(-)$ & & $\begin{array}{l}.028 \\
(.082)\end{array}$ & & & \\
\hline Moldova $\times$ coercive paternalism $(-)$ & & $\begin{array}{l}-.140 \\
(.084)\end{array}$ & & & \\
\hline Control group & & $\begin{array}{l}-.037 \\
(.082)\end{array}$ & & & \\
\hline
\end{tabular}

Entries are estimates of treatment effects (relative to the specified baseline categories) with standard errors in parentheses. ${ }^{*}=p<.10,{ }^{* *}=p<.05,{ }^{* * *}=p<.01$. All statistical significance tests are two-tailed.

\section{FIGURE 2. Means and 95\% Confidence Intervals by Experimental Groups}

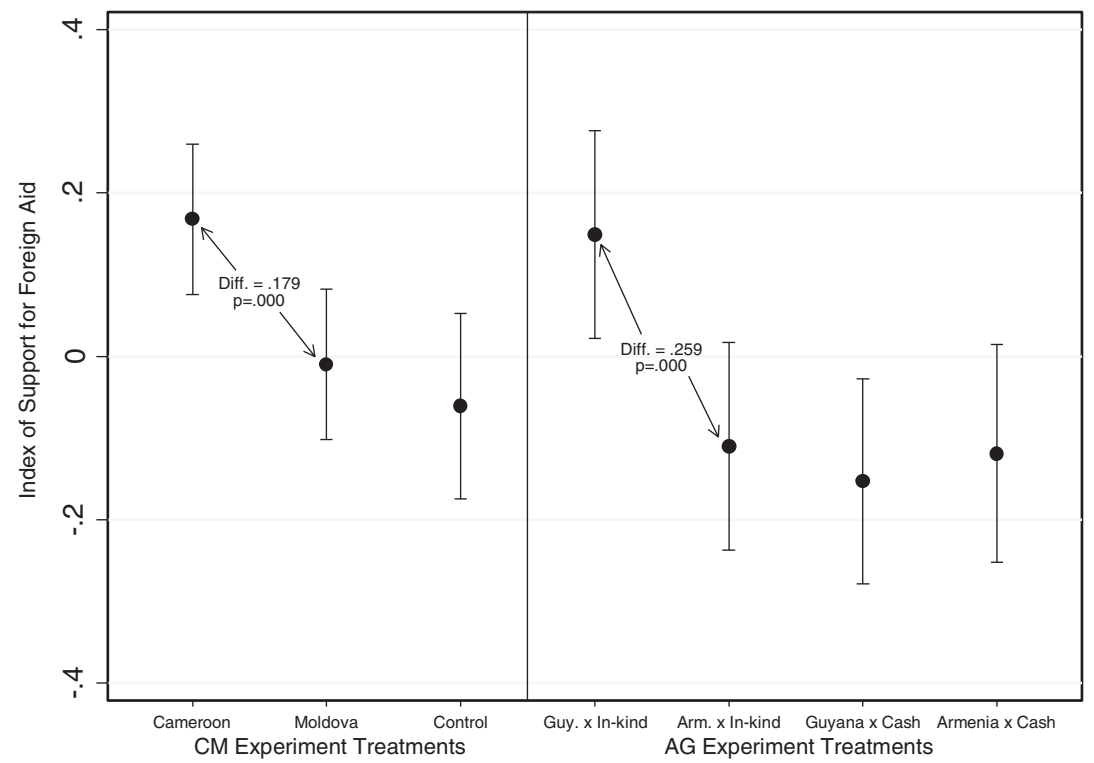


collection of treatment effects provides strong initial evidence for the presence of racial paternalism. ${ }^{19}$

\section{Sources of Race-of-Recipient Treatment Effects}

These race-of-recipient treatment effects are suggestive, but they alone do not establish the presence of a racially prejudiced view that sees foreign blacks as unable to help themselves and in need of saving and control by donors. To do so, it is necessary to determine that paternalistic views about the foreign poor, and not just perceptions of material need, mediate the race-ofrecipient treatment effects.

A serious alternative explanation to the racial paternalism argument is that the driver of the race-ofrecipient effect is a sincere generosity for a group of foreigners (blacks) that is in reality poorer, and thus more deserving of aid, than the comparison group (whites). Key to this alternative is that, despite the experiments' attempts to equilibrate objective need across the two different races by reporting average incomes, the two countries used for the black-recipient treatments (Cameroon and Guyana) are genuinely less developed than their white-majority paired country in other ways. For example, despite the similar GDPs per capita, Moldova and Armenia have better human development standards (i.e., health and education outcomes) than Cameroon and Guyana, respectively. ${ }^{20}$ Given the near-anonymity of these four countries to U.S. citizens, it is surely the case that few respondents had information about nonincome forms of development in the country about which they were cued. However, they could still have used readily available heuristics or stereotypes (e.g., Africa as a war-torn basket case) that would lead them to the correct conclusion that, say, Cameroonians are poorer on average in health and educational attainment.

To be clear, if need-based generosity toward blacks were the true mediating factor behind the race-ofrecipient effects, it would still be a novel finding. After all, in the American context, the uncharitable resentment paradigm stipulates that the lower average income of African-Americans does not produce a commensurate response in beneficence from whites. But such a finding would contradict the claim that racial paternalism is at work. Regardless, I show that the perceived material needs of recipients are not the mediators behind the treatment effects.

\footnotetext{
19 The main effects of the form of paternalism in the CM experiment are also interesting. (See Table 1.) Respondents do not mind some coercion in foreign aid when the coercion is framed positively. Support for foreign aid did fall, however, when coercion was framed negatively. Norms of individual rights may be responsible for this backlash when coercion is explicit and negative (Mendelberg 2001), or perhaps the costs of coercion make some individuals skittish. Neither, however, exerts a significant impact on the effect of race. ${ }^{20}$ Choosing pairings with these gaps was done out of necessity: only a scarce few African countries, like Gabon and Mauritius, have life expectancies and other human development indicators that are higher than Moldova's, but these have average incomes that are multiples of Moldova's.
}

Given its importance in the literature on domestic redistribution across racial and ethnic lines, I also consider the role of out-group resentment, even though the experimental treatment effects suggest that something very different is at play when moving to the international sphere. Nonetheless, two resentment-related narratives are compatible with the treatment effects observed above and are thus plausible. One is that out-group resentment by white Americans is still decreasing their generosity toward foreign blacks (as predicted by the uncharitable resentment model), but that this suppression of the race-of-recipient treatment is swamped by some other variable that is having a positive effect, such as foreign blacks' greater perceived need. In other words, my white respondents could still be more miserly to foreigners of African descent precisely because of their race, but this effect could be outweighed by respondents' desire to help those who are perceived to be more materially deprived. A second possibility is that I have uncovered a racial resentment not toward foreign blacks but toward foreign whites. Perhaps my respondents viewed Armenians and Moldovans as unworthy of charity because they are poor despite the perceived advantages that come from being European. This already appears to not be the case, since in the $\mathrm{CM}$ experiment respondents with the Moldovan primes were not less supportive of aid than those in the control group, but it is worth keeping in mind as a possibility.

I test these competing accounts of the race treatment effect using mediation analysis and three indicators that are derived from post-treatment measures in the $\mathrm{CM}$ experiment. My argument about race and paternalism is tested using a new index called Perception of foreign poor's agency and derived from the shared variation among three survey items, each of which captured the respondent's perception of agency among the foreign poor. Recently, indicators of agency perception and mind attribution have seen widespread use in social psychology (Gray et al. 2011; Kozak, Marsh, and Wegner 2006), but I do not adopt these verbatim because they would not translate well to the macrodevelopment issues in play: psychologists are typically interested in perceptions of agency among targeted individuals or well-defined groups (e.g., "how capable is this person or group of planning?"). Instead, I incorporated the spirit of some of these indicators by constructing items designed to measure adherence to certain stereotypes, as pinpointed by various actors in the foreign aid debate, about agency among the foreign poor. Respondents registered their opinion of the three statements using a five-point strongly-agree-to-strongly-disagree scale. The wordings for the three items and the ratio of agree to disagree responses are as follows:

Perception of agency 1: "Because of difficult economic circumstances, people in poor countries are unable to help themselves get richer." (42\% agree to $31 \%$ disagree)

Perception of agency 2: "There is little that people in poor countries can do by themselves to improve their livelihoods." (26\% agree to $50 \%$ disagree) 
Perception of agency 3: "The only way poor countries could grow richer is with financial help from rich countries." $(30 \% \text { agree to } 45 \% \text { disagree })^{21}$

The three variables have high reliability (Cronbach's alpha $=.79$ ). The index (again created from a principal components analysis) is coded so that higher values correspond to perceptions of little or no agency.

I posit the following causal model of foreign aid attitudes:

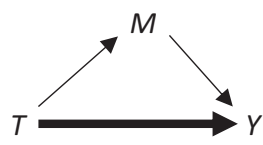

where $T_{i}$ is the Cameroon treatment, $Y_{i}$ is the Index of support for foreign aid outcome variable, and $M_{i}$ is the Perception of foreign poor's agency index, the mediator variable. The mediation analysis parses the total effect of $T_{i}$ on $Y_{i}$ into two parts: the mediated effect of $T_{i}$ that runs through $M_{i}$ (as represented by the two thin arrows) and the direct effect of $T$ that does not run through $M_{i}$ (as represented by the thick arrow). Intuitively, I expect to find that perceptions of agency mediate a significant portion of the effect of race-ofrecipient on foreign aid attitudes: Being prompted to think about blacks makes respondents less likely to think the foreign poor can take positive action to improve their lot, which in turn boosts their support for foreign aid.

To estimate this mediation effect, I use the techniques developed by Imai, Keele, Tingley, and Yamamoto (2011). ${ }^{22}$ This entailed the estimation of two equations and then the performance of a simulation. The first equation is

$$
M_{i}=\alpha_{1}+\lambda_{1} T_{i}+\boldsymbol{X} \beta+\varepsilon_{i 1} .
$$

This is a least-squares regression in which the left-handside variable is the agency perceptions index $\left(M_{i}\right)$ and the right-hand side contains the Cameroonian treatment dummy $\left(T_{i}\right)$ plus a matrix of control variables $(\boldsymbol{X})$ that were measured before the treatment was administered. If my argument is correct, such that the effect of race occurs by shifting perceptions of the foreign poors' agency, then a first necessary condition is that, in this equation, the Cameroonian treatment will produce a positive effect on the agency perceptions index: $\lambda_{1}>0$. I set up the model to explore agency perceptions as a

\footnotetext{
${ }^{21}$ Although this third item makes a loose reference to foreign aid (thus raising concerns of tautology), it is important to keep in mind that the basis for the mediation claim is not that this item (and the index) has a simple correlation with the dependent variable. It is rather that the Cameroon prime boosts agreement with this item. Regardless, the mediation analysis of the AG experiment below does not contain this item.

${ }^{22}$ I used "mediation," the R package developed by Dustin Tingley et al: http://cran.r-project.org/web/packages/mediation/vignettes/ mediation.pdf.
}

mediator of the Cameroonian main effect (relative to the Moldovan treatments) on the dependent variable. ${ }^{23}$

The second equation is as follows:

$$
Y_{i}=\alpha_{2}+\lambda_{2} T_{i}+\gamma M_{i}+\boldsymbol{X} \beta+\varepsilon_{i 2}
$$

This is also a least-squares regression, but with the foreign aid attitudes index $\left(Y_{i}\right)$ on the left-hand side and the Cameroonian treatment indicator $\left(T_{i}\right)$, the perceptions of agency mediator $\left(M_{i}\right)$, and the pretreatment controls $(\boldsymbol{X})$ on the right-hand side. A second necessary condition for confirmation of the racial paternalism argument is that $\gamma>0$, meaning the agency perceptions index is having a positive effect on the foreign aid attitudes variable, even when controlling for the treatment (Baker 2009, 236).

With the coefficients and standard errors from these two equations in hand, the procedure then calculates the average causal mediation effect (ACME), which is the estimate of the effect that the Cameroonian treatment $\left(T_{i}\right)$ exerted on foreign aid attitudes $\left(Y_{i}\right)$ through the mediator variable $\left(M_{i}\right)$. A third condition is that this ACME will be positive. The mechanics of the procedure are to first use Equation (1) to simulate predictions for $M_{i}$ in both the Cameroonian treatment state $\left(T_{i}=1\right)$ and the Moldovan treatment state $\left(T_{i}=0\right)$, subsequently plug these predicted $M_{i}$ 's into Equation (2) for $T_{i}=1$ and then $T_{i}=0$ to simulate predictions of the outcome variable $Y_{i}$, and finally compare the average differences in the outcome variable between the two states. This average is the ACME, and it can be expressed both in original units and also as a share of the total effect (i.e., the mediated effect plus the direct effect) of $T_{i}$ on $Y_{i} .^{24}$

To test the main alternative explanation, I consider a mediator that gauges perceived living standards. Respondents guessed the percent of citizens in the country on which they were primed that had at least two meals per day and indoor plumbing. The mean of these two percentages is the Perceived living standards index. I also conduct a third mediation analysis testing to see the extent to which a Resentment of the foreign poor index mediates the race-of-recipient treatment. This index is modeled on the often-used racial resentment index of the American National Election Studies (Kinder and Sanders 1996), replacing, for example, references in the original questions to "blacks" with references to

\footnotetext{
${ }^{23}$ In other words, I collapse the three Cameroonian treatment groups $\left(T_{i}=1\right)$ into a single category and designate the three Moldovan treatment groups (also collapsed into a single category, $\left.T_{i}=0\right)$ as the omitted baseline category. This increases statistical power substantially, since the treatment uses information from $3 / 7$ ths of the sample instead of just one of the seven experimental groups. To properly identify the Cameroonian main effect, I include among the control variables dummies for two of the three form-of-paternalism treatments.

${ }^{24}$ The validity of the ACME as an estimate of the true mediation effect depends on whether the sequential ignorability assumption holds (Imai et al, 2011). I discuss this and sensitivity analyses of the mediation results in the Online Appendix.
} 
TABLE 2. Mediation Analysis Results for the CM Experiment

\begin{tabular}{|c|c|c|c|c|c|c|}
\hline \multirow[b]{2}{*}{ Left-hand-side variable: } & \multicolumn{2}{|c|}{$\begin{array}{l}\text { 1. Perception of foreign } \\
\text { poor's agency index }\end{array}$} & \multicolumn{2}{|c|}{$\begin{array}{l}\text { 2. Perceived living } \\
\text { standards index }\end{array}$} & \multicolumn{2}{|c|}{$\begin{array}{l}\text { 3. Resentment of foreign } \\
\text { poor index }\end{array}$} \\
\hline & $\begin{array}{l}\text { Equation } \\
\qquad \begin{array}{c}(1) \\
\left(M_{i}\right) \\
(1.1)\end{array}\end{array}$ & $\begin{array}{c}\text { Equation } \\
\qquad(2) \\
\left(Y_{i}\right) \\
(1.2)\end{array}$ & $\begin{array}{l}\text { Equation } \\
\qquad \begin{array}{l}(1) \\
\left(M_{i}\right) \\
(2.1)\end{array}\end{array}$ & $\begin{array}{l}\text { Equation } \\
\qquad(2) \\
\left(Y_{i}\right) \\
(2.2)\end{array}$ & $\begin{array}{l}\text { Equation } \\
\qquad \begin{array}{l}(1) \\
\left(M_{i}\right) \\
(3.1)\end{array}\end{array}$ & $\begin{array}{l}\text { Equation } \\
\qquad \begin{array}{c}(2) \\
\left(Y_{i}\right) \\
(3.2)\end{array}\end{array}$ \\
\hline Mediator & & $\begin{array}{l}.526 * * * \\
(.018)\end{array}$ & & $\begin{array}{l}.001 \\
(.001)\end{array}$ & & $\begin{array}{l}-.530^{* * *} \\
(.024)\end{array}$ \\
\hline Cameroon & $\begin{array}{l}.098^{* *} \\
(.047)\end{array}$ & $\begin{array}{l}.117^{* * *} \\
(.038)\end{array}$ & $\begin{array}{c}-9.287^{* * *} \\
(.943)\end{array}$ & $\begin{array}{l}.188^{* * *} \\
(.046)\end{array}$ & $\begin{aligned}-.037 \\
(.038)\end{aligned}$ & $\begin{array}{l}.150^{* * *} \\
(.040)\end{array}$ \\
\hline Moldova & $\begin{array}{l}\text { Baseline } \\
\text { category }\end{array}$ & $\begin{array}{l}\text { Baseline } \\
\text { category }\end{array}$ & $\begin{array}{l}\text { Baseline } \\
\text { category }\end{array}$ & $\begin{array}{l}\text { Baseline } \\
\text { category }\end{array}$ & $\begin{array}{l}\text { Baseline } \\
\text { category }\end{array}$ & $\begin{array}{l}\text { Baseline } \\
\text { category }\end{array}$ \\
\hline Coercive paternalism (+) & $\begin{array}{l}.011 \\
(.057)\end{array}$ & $\begin{aligned}-.052 \\
(.046)\end{aligned}$ & $\begin{array}{l}-1.272 \\
(1.151)\end{array}$ & $\begin{aligned}-.059 \\
(.055)\end{aligned}$ & $\begin{aligned}-.057 \\
(.046)\end{aligned}$ & $\begin{array}{c}-.077 \\
(.049)\end{array}$ \\
\hline Coercive paternalism (-) & $\begin{array}{l}.008 \\
(.057)\end{array}$ & $\begin{array}{l}-.159^{* * *} \\
(.046)\end{array}$ & $\begin{array}{c}-1.024 \\
(1.147)\end{array}$ & $\begin{array}{c}-.159^{* *} \\
(.055)\end{array}$ & $\begin{array}{l}.044 \\
(.046)\end{array}$ & $\begin{array}{l}-.132^{* *} \\
(.049)\end{array}$ \\
\hline Control group & $\begin{array}{l}.063 \\
(.073)\end{array}$ & $\begin{aligned}-.079 \\
(.058)\end{aligned}$ & $\begin{array}{l}-8.010^{* * *} \\
(1.463)\end{array}$ & $\begin{aligned}-.050 \\
(.071)\end{aligned}$ & $\begin{aligned}-.021 \\
(.059)\end{aligned}$ & $\begin{aligned}-.057 \\
(.063)\end{aligned}$ \\
\hline $\begin{array}{l}\text { Ideology (extremely liberal to } \\
\text { extremely conservative) }\end{array}$ & $\begin{array}{l}-.088^{* * *} \\
(.019)\end{array}$ & $\begin{array}{l}-.080^{* * *} \\
(.015)\end{array}$ & $\begin{aligned}-.481 \\
(.379)\end{aligned}$ & $\begin{array}{l}-.127^{* * *} \\
(.018)\end{array}$ & $\begin{array}{l}.090^{* * *} \\
(.015)\end{array}$ & $\begin{array}{l}-.079^{* * *} \\
(.016)\end{array}$ \\
\hline $\begin{array}{l}\text { Partisanship (strong Democrat } \\
\text { to strong Republican) }\end{array}$ & $\begin{array}{l}-.071^{* * *} \\
(.013)\end{array}$ & $\begin{array}{l}-.030^{* *} \\
(.011)\end{array}$ & $\begin{array}{l}.500^{*} \\
(.269)\end{array}$ & $\begin{array}{l}-.069^{* * *} \\
(.013)\end{array}$ & $\begin{array}{l}.072^{* * *} \\
(.011)\end{array}$ & $\begin{aligned}-.029^{*} \\
(.011)\end{aligned}$ \\
\hline Education & $\begin{aligned}-.009 \\
(.012)\end{aligned}$ & $\begin{array}{l}.103^{* * *} \\
(.011)\end{array}$ & $\begin{aligned}-.349 \\
(.239)\end{aligned}$ & $\begin{array}{l}.098^{* * *} \\
(.011)\end{array}$ & $\begin{array}{l}-.054^{* * *} \\
(.010)\end{array}$ & $\begin{array}{l}.070^{* * *} \\
(.010)\end{array}$ \\
\hline Constant & $\begin{array}{l}.710 \\
(.149)\end{array}$ & $\begin{aligned}-.584 \\
(.120)\end{aligned}$ & $\begin{array}{l}39.671 \\
(2.972)\end{array}$ & $\begin{aligned}-.226 \\
(.148)\end{aligned}$ & $\begin{array}{l}2.634 \\
(.119)\end{array}$ & $\begin{array}{l}1.183 \\
(.142)\end{array}$ \\
\hline $\begin{array}{l}\text { ACME } \\
{[95 \% \text { confidence interval] }}\end{array}$ & \multicolumn{2}{|c|}{$\begin{array}{l}.052^{* *} \\
{[.005, .101]}\end{array}$} & \multicolumn{2}{|c|}{$[-.032, .008]$} & \multicolumn{2}{|c|}{$[-.020, .060]$} \\
\hline $\begin{array}{l}\text { Direct effect } \\
\text { [95\% confidence interval] } \\
\text { Total effect } \\
\text { [95\% confidence interval] } \\
N\end{array}$ & $\begin{array}{r}.1 \\
.04 \\
.1 \\
.085 \\
2\end{array}$ & $\begin{array}{l}* * \\
191] \\
* * \\
254]\end{array}$ & $\begin{array}{r}.19 \\
{[.099} \\
.17 \\
{[.089} \\
2(\end{array}$ & 79] & $\begin{array}{r}.1 \\
.07 \\
.1 \\
.08 \\
2\end{array}$ & $\begin{array}{l}2 * * \\
230] \\
26 \\
260]\end{array}$ \\
\hline
\end{tabular}

"people in poor countries."25 (Full wordings are in the Online Appendix.)

Table 2 reports the results of two mediation analyses on the CM experimental data, with the main parameter estimates of interest shaded in grey. ${ }^{26}$ The bar for

\footnotetext{
${ }^{25}$ Interestingly, resenters are not paternalists. The correlation between the Perception of the foreign poor's agency index and the Resentment of the foreign poor index is -.41 . Paternalists (or, more precisely, those who see little agency in the foreign poor) are less likely to be resentful of the foreign poor than are those who see the foreign poor as being able to control their livelihood outcomes. In other words, resenters are likely to view the foreign poor as having agency - it is just bad agency that leads to their own impoverishment. By contrast, paternalists are less resentful of the foreign poor because they see the poor as immobilized victims. In short, paternalism is not borne of resentment, it is borne of pity.

${ }^{26}$ Rates of missing data due to nonresponse and nonopinionation were minimal in the CM survey because respondents were not offered "don't know" as an option (Berinsky 2004; Krosnick et al. 2002). (See Online Appendix for rates of missingness by question.) To avoid listwise deletion, in the rare instances when respondents skipped a question without registering a response, their score on the relevant index was simply determined using their response to the other questions used to construct that index.
}

finding significant mediation effects is high, since three different conditions must hold, but columns 1.1 and 1.2 show that all three needed to support my argument hold. The Cameroonian treatment has a positive effect on the agency perceptions index, as captured by the first coefficient listed in column 1.1: respondents cued to think about Africans believed the foreign poor to have fewer agentic capacities for development than those who were cued to think about East Europeans. The second condition is that the perception of the foreign poor's agency mediator exerts an effect on the dependent variable, and this is shown to be the case in the first coefficient listed in column 1.2: the new index turns out to be a strong correlate of mass support for foreign aid. The third condition is that the ACME is nonzero, and this too is confirmed at the bottom of the table. The ACME is $.052(p=.038)$, and the lower bound of its $95 \%$ confidence interval is above zero. Given that the total effect of the Cameroonian treatment is estimated to be .169 , an estimated $31 \%$ of the total effect is mediated through the agency perceptions index. In sum, an important portion of the increased support for foreign aid among Africa-cued respondents is due to the 
mass belief that Africans have more limited capacity for positive agency than Eastern Europeans.

By contrast, only one of these conditions holds when I test perceived living standards as a potential mediator, which enables me to soundly reject the alternative hypothesis that perceived differences between Cameroon and Moldova in material needs are driving the observed race-of-recipient treatment effect. The perceived living standards mediator does pass the first test: respondents in the Cameroonian treatments estimated living standards to be lower than did those in the Moldovan treatments. (See the topmost coefficient in column 2.1.) On average, respondents thought that nine percent (half a standard deviation) fewer households in Cameroon ate two meals per day and had indoor plumbing. However, perceived living standards has no correlation whatsoever with foreign aid attitudes (topmost coefficient in column 2.2), so the ACME is also a statistical zero. In sum, it is perceptions of recipient agency, and not perceived material need, that determine the impact of race-of-recipient on foreign aid attitudes. Indeed, I can go a step further and assert that white Americans' perceptions of objective need are themselves irrelevant to their beliefs about development assistance.

The rightmost two columns in Table 2 also show that resentment is not mediating the treatment effect. Here, the failure lies in the first equation: resentment of the foreign poor is not boosted by the Cameroonian treatment. If anything, resentment falls with this treatment, although the effect is smaller than its standard error. Resentment is correlated with support for foreign aid, as evidenced by the topmost coefficient in column 3.2, but this is an observational finding that has nothing to do with race or the experimental manipulation. The ACME is small and not statistically different from zero.

I conducted a very similar trio of mediation analyses with the data from the AG experiment, seeking to break down the effect of the Guyana $\times$ In-kind treatment $\left(T_{i}=1\right)$ relative to the two Armenian treatments $\left(T_{i}=0\right) \cdot{ }^{27}$ For this survey, and in the interests of robustness checking the $\mathrm{CM}$ findings, the agency perceptions index was slightly different. ${ }^{28}$ For two of them, respondents were asked to self-place on a fivepoint scale, with competing statements representing the opposite extremes of the scale:

Perception of agency 1: (1) "Because of difficult economic circumstances, people in poor countries are unable to help themselves get richer." versus (5) "People in poor countries are able to do things that can help themselves get richer." ( $29 \%$ chose 1 or $2,24 \%$ chose 4 or 5 )

\footnotetext{
${ }^{27}$ That is, the two Armenian treatment groups are collapsed into a single category and I control for the Guyana $\times$ Unconditional cash treatment with a dummy.

${ }^{28}$ Since they were all worded so that agreement equated to perceptions of low or no agency, the CM agency items were potentially subject to acquiescence bias. The GA items were reworded to avoid this problem. The consistency in results between the two surveys, however, suggests that acquiescence bias is of little consequence in the $\mathrm{CM}$ experiment.
}

Perception of agency 2: (1) "There is a lot that poor countries and their citizens can do by themselves to improve their own livelihoods." versus (5) "There is little that poor countries and their citizens can do by themselves to improve their own livelihoods." (16\% chose 1 or $2,41 \%$ chose 4 or 5 )

The third item used the five-point strongly-agree-tostrongly-disagree response set used in the CM experiment and was worded as follows:

Perception of agency 3: "When it comes to improving their economic standard of living, people in poor countries are like extremely sick or paralyzed patients; they are completely unable to help themselves." (23\% agree to $37 \%$ disagree)

The three items had a Cronbach's alpha of .65 , so I used them to create another perception of foreign poor's agency index generated by a principal components analysis. The perceived living standards index was equivalent to that used in the CM experiment. A resentment index, again inspired by the ANES racial resentment battery, was also considered (and full wordings are in the Online Appendix). ${ }^{29}$

The results, reported in Table 3, are striking in their closeness to those reported in Table 2. All three conditions hold in support of the claim that perceptions of foreign agency are a mediator of the race-of-recipient effect. The relevant coefficients in columns 1.1 and 1.2 are statistically significant, and the ACME is $.060(p=$ .052 ), about $30 \%$ of the total effect. This contrasts with an ACME of zero when the mediator is perceived living standards, and perceptions of material need again has no correlation with support for foreign aid (as evidenced by the topmost coefficient in 2.2). Similarly, resentment does not account for the treatment effect: respondents in the Guyana $\times$ in-kind treatment were actually less likely to express resentment toward the foreign poor than those in the Armenian treatments, although (again) this effect is not statistically significant (topmost coefficient in 3.1). In sum, the evidence shows that differential perceptions of foreign whites' and foreign blacks' capacity to act, and not perceived differences in their material wealth, drive the race-ofrecipient effects on foreign aid attitudes.

\section{IMPLICATIONS FOR UNDERSTANDING THE FOREIGN AID REGIME}

These findings on public opinion hold important implications for understanding the modern development assistance regime. Two sets of issues merit comment. First, Africa sells. Sachs's speculation that Westerners dislike aid to Africa because they resent its people

\footnotetext{
${ }^{29}$ As in the CM experiment, respondents to the AG experiment were not offered explicit "don't know" options, so the relatively rare nonresponses to the index items were treated the same in both surveys. (See footnote 26.) However, "not sure" was an explicit option in the partisanship and ideology questions. These missing responses were multiply imputed, and the models in Table 3 estimated, according to the procedures laid out in King et al. (2001).
} 
TABLE 3. Mediation Analysis Results for the AG Experiment

\begin{tabular}{|c|c|c|c|c|c|c|}
\hline \multirow[b]{2}{*}{ Left-hand-side variable: } & \multicolumn{2}{|c|}{$\begin{array}{l}\text { 1. Perception of foreign } \\
\text { poor's agency index }\end{array}$} & \multicolumn{2}{|c|}{$\begin{array}{l}\text { 2. Perceived living } \\
\text { standards index }\end{array}$} & \multicolumn{2}{|c|}{$\begin{array}{l}\text { 3. Resentment of } \\
\text { foreign poor index }\end{array}$} \\
\hline & $\begin{array}{l}\text { Equation } \\
\qquad \begin{array}{c}(1) \\
\left(M_{i}\right) \\
(1.1)\end{array}\end{array}$ & $\begin{array}{c}\text { Equation } \\
\qquad(2) \\
\left(Y_{i}\right) \\
(1.2)\end{array}$ & $\begin{array}{l}\text { Equation } \\
\qquad \begin{array}{l}(1) \\
\left(M_{i}\right) \\
(2.1)\end{array}\end{array}$ & $\begin{array}{c}\text { Equation } \\
\qquad(2) \\
\left(Y_{i}\right) \\
(2.2)\end{array}$ & $\begin{array}{l}\text { Equation } \\
\qquad(1) \\
\left(M_{i}\right) \\
(3.1)\end{array}$ & $\begin{array}{c}\text { Equation } \\
(2) \\
\left(Y_{i}\right) \\
(3.2)\end{array}$ \\
\hline Mediator & & $\begin{array}{l}.388^{* * *} \\
(.030)\end{array}$ & & $\begin{aligned}-.000 \\
(.001)\end{aligned}$ & & $\begin{array}{l}-.504^{* * *} \\
(.034)\end{array}$ \\
\hline Guyana $\times$ In-kind & $\begin{array}{l}.151^{* *} \\
(.077)\end{array}$ & $\begin{array}{l}.139 * * \\
(.069)\end{array}$ & $\begin{array}{r}-2.699 \\
(1.756)\end{array}$ & $\begin{array}{l}.197^{* * *} \\
(.076)\end{array}$ & $\begin{array}{l}-.086 \\
(.070)\end{array}$ & $\begin{array}{l}.154^{* * *} \\
(.066)\end{array}$ \\
\hline Armenian treatment & $\begin{array}{l}\text { baseline } \\
\text { category }\end{array}$ & $\begin{array}{l}\text { baseline } \\
\text { category }\end{array}$ & $\begin{array}{l}\text { baseline } \\
\text { category }\end{array}$ & $\begin{array}{l}\text { baseline } \\
\text { category }\end{array}$ & $\begin{array}{l}\text { baseline } \\
\text { category }\end{array}$ & $\begin{array}{l}\text { baseline } \\
\text { category }\end{array}$ \\
\hline Guyana $\times$ unconditional cash & $\begin{array}{c}-.103 \\
(.077)\end{array}$ & $\begin{array}{c}-.022 \\
(.068)\end{array}$ & $\begin{array}{c}-1.604 \\
(1.756)\end{array}$ & $\begin{array}{c}-.062 \\
(.074)\end{array}$ & $\begin{array}{l}.083 \\
(.071)\end{array}$ & $\begin{array}{c}-.021 \\
(.065)\end{array}$ \\
\hline $\begin{array}{l}\text { Ideology (extremely liberal to } \\
\text { extremely conservative) }\end{array}$ & $\begin{array}{r}-.032 \\
(.030)\end{array}$ & $\begin{array}{l}-.090^{* * * *} \\
(.028)\end{array}$ & $\begin{array}{l}.306 \\
(.711)\end{array}$ & $\begin{array}{l}-.102^{* * *} \\
(.028)\end{array}$ & $\begin{array}{l}.198^{* * *} \\
(.026)\end{array}$ & $\begin{aligned}-.002 \\
(.029)\end{aligned}$ \\
\hline $\begin{array}{l}\text { Partisanship (strong Democrat } \\
\text { to strong Republican) }\end{array}$ & $\begin{array}{l}-.096^{* * *} \\
(.023)\end{array}$ & $\begin{array}{c}-.064^{* *} \\
(.021)\end{array}$ & $\begin{array}{l}1.004^{*} \\
(.601)\end{array}$ & $\begin{array}{l}-.101^{* * *} \\
(.021)\end{array}$ & $\begin{array}{l}.063^{* * *} \\
(.020)\end{array}$ & $\begin{array}{l}-.069 * * * \\
(.020)\end{array}$ \\
\hline Education & $\begin{aligned}-.019 \\
(.021)\end{aligned}$ & $\begin{array}{l}.067^{* * *} \\
(.019)\end{array}$ & $\begin{array}{c}-1.030^{* *} \\
(.474)\end{array}$ & $\begin{array}{l}.060^{* * *} \\
(.020)\end{array}$ & $\begin{array}{c}-.039^{* *} \\
(.019)\end{array}$ & $\begin{array}{l}.040^{* *} \\
(.018)\end{array}$ \\
\hline Constant & $\begin{array}{l}.536 \\
(.123)\end{array}$ & $\begin{array}{l}.336 \\
(.116)\end{array}$ & $\begin{array}{l}34.389 \\
(3.112)\end{array}$ & $\begin{array}{l}.545 \\
(.134)\end{array}$ & $\begin{aligned}-.908 \\
(.114)\end{aligned}$ & $\begin{array}{l}.086 \\
(.012)\end{array}$ \\
\hline $\begin{array}{l}\text { ACME } \\
{[95 \% \text { confidence Interval] }}\end{array}$ & \multicolumn{2}{|c|}{$[-.001, .120]$} & \multicolumn{2}{|c|}{$[-.011, .011]$} & \multicolumn{2}{|c|}{$[-.028, .117]$} \\
\hline Direct effect & \multicolumn{2}{|c|}{$.137^{* *}$} & \multicolumn{2}{|c|}{$.197^{* * *}$} & \multicolumn{2}{|c|}{$.154^{* *}$} \\
\hline [95\% confidence Interval] & \multicolumn{2}{|c|}{$[.004, .271]$} & \multicolumn{2}{|c|}{$[.046, .349]$} & \multicolumn{2}{|c|}{$[.026, .281]$} \\
\hline Total effect & & \multicolumn{2}{|c|}{$.197^{* * *}$} & \\
\hline [95\% confidence Interval] & \multicolumn{2}{|c|}{$[.049, .345]$} & \multicolumn{2}{|c|}{$[.048, .347]$} & \multicolumn{2}{|c|}{$[.049, .347]$} \\
\hline
\end{tabular}

is inaccurate, as is the intimation that aid proponents should hide the black faces they intend to help when promoting aid to donor publics. To the contrary, portraying potential recipients of African descent is good marketing. It is perhaps not a coincidence that the largest aid initiative for a single global problem in U.S. history was the President's Emergency Plan for AIDS Relief (PEPFAR), the program to combat HIV/AIDS mostly in Africa and the Caribbean that faced relatively minimal domestic resistance (Kharas 2008, 54).

Yet this finding of relative charitableness toward Africa-descended persons rests on some uncomfortable truths. It is the "pornography of violence," 30 immiseration, and helplessness in Western media portrayals of Africa that is ultimately good for mass support for aid flows to the continent, and, before boosting support, this media narrative first feeds Westerners' underestimations of Africans' agency. Moreover, whereas Africa does sell, so do paternalistic interventions. Tying the hands of recipients is more than just a means for policy-makers and bureaucrats to nudge or coerce recipients into presumably using aid more effectively. It is necessary politics, since donor publics do not like the thought of their tax dollars being used unfettered

\footnotetext{
${ }^{30}$ Mamdani 2009, 56.
}

by foreign aid recipients, especially ones of African descent. This suggests a potentially gloomy political outlook for the newfound efforts to deliver aid in the form of unconditional cash grants, which thus far seem to be more effective for recipient welfare than more paternalistic forms of aid delivery (Blattman, Fiala, and Martinez 2014).

Second (and more speculatively), the findings in this article may shed some light on why the foreign aid regime is so rife with paternalistic interference. According to Abhijit Banerjee and Esther Duflo, the prevailing mindset among donor-country politicians and aid bureaucrats is that "poor people should be enticed to do what we ... think is good for them" (2011, 9). Similarly, Michael Barnett claims that "paternalism is the form of power most familiar to humanitarians" (Barnett 2011, 233). Vast amounts of resources are expended to have an enormous bureaucratic infrastructure - one that includes donor-country aid agencies, international nongovernmental organizations, poor-country cabinet ministries, and multilateral aid institutions - dictate how funds are channeled from developed-world taxpayers to developing-world recipients (Gibson et al. 2005).

Moreover, this may be linked to race. For example, developing countries with black majorities are less 
likely than those with nonblack majorities to receive their development assistance in the form of country programmable aid (CPA), which is "the portion of aid on which recipient countries have, or could have, a significant say" (Benn, Rogerson, and Steensen 2010, 1; see also Kharas 2008). From 2000 to 2011, countries with black majorities received 63 percent of their bilateral aid as CPA, whereas the rate among all other countries was 79 percent. ${ }^{31}$ In other words, black-majority countries are more likely to receive official development assistance in a form that gives them little control over how to use it.

The findings in this article about attitudes within one donor-country public implicitly nominate a pair of potential causes for the foreign aid regime's deep paternalism. One is that aid policymakers and activists are following the prejudiced paternalistic cues of public opinion. Scholars of U.S. politics are generally skeptical that public opinion influences policy on foreign aid (Berinsky 2007; Jacobs and Page 2005), but in actuality the matter has received little thorough research (Milner and Tingley 2013b). Even if no American politician has ever won or lost an election because of public opinion on the foreign aid issue, policymakers and aid bureaucrats may follow aid-related cues from mass publics, using things like variation in media attention and private contributions to different humanitarian disasters as gauges of the political feasibility of certain aid flows. For example, in 2010, both private and official donations from the United States to Haiti after its earthquake outran those to Pakistan after its floods. ${ }^{32}$

A second possibility is that $\mathrm{I}$ have pinpointed a racial paternalism carried not just by the mass public but also, as Easterly alleges, by aid policymakers and activists themselves. In this sense, this article stands alongside studies that seek to explain difficult-to-study, internationally relevant elite behaviors by looking at mass behavior (e.g., Tomz and Weeks 2013). Of course, accusing aid bureaucrats of racial paternalism is a serious charge, so a more definitive conclusion will require further research.

\section{CONCLUSION}

Counter to the stubborn finding that uncharitable resentment characterizes mass attitudes toward domestic redistribution across racial lines, this study finds a scenario in which individuals want their government to be more financially generous with a racial out-group than

\footnotetext{
${ }^{31}$ Country programmable aid is a subcategory of all official development assistance created by the OECD for classification purposes. CPA is aid that is an actual flow to the receiving country and over which there has been some mutual collaboration and planning between donors and receivers. Official Development Assistance that is not a flow of resources to a less developed country (e.g., administrative costs in the donor country) or that is inherently unpredictable and thus unable to be programmed or influenced by receiving countries (e.g., food aid) is tallied as non-CPA. For full details see Benn, Rogerson, and Steensen 2010. The reported percentages are based on the author's own calculations using data from http://www.oecd. org/dac/aid-architecture/cpa.htm

32 Data are from http://aiddata.org/.
}

with a racial in-group. I find that American whites are more supportive of foreign aid when prompted to think about aid to foreigners of African descent than when thinking about aid to Eastern Europeans. This is not, however, a realm in which there is an absence of racial prejudice. Rather, I confirm many of the claims and fears of foreign aid skeptics: white Americans view the foreign poor of darker skin through a paternalistic lens that underestimates their capacities to be active agents in bringing about improvements to their own lives.

To be sure, this is far from the first study to find that intergroup perceptions are not always resentful; however, most previous such efforts have assumed the opposite of uncharitable resentment to be benevolent prejudice-one that creates warmth toward an outgroup by stereotyping its allegedly positive traits (Fiske et al. 2002; Jackman 1994). My findings root notions of paternalistic prejudice not in benevolence-since paternalism need not always be motivated by warmth (Soss, Fording, and Schramm 2011) - but in underestimations of agentic capacity. Given the standard American media portrayals of Africa as well as the sheer physical and symbolic distance between Western and African lives, white Americans are more likely to treat foreigners of African descent as enigmatic others with less than full capacities to plan and act.

Because of the specifics of these dyads, I do not contend that attitudes about foreign aid across racial lines will always be characterized by paternalism. This article compares just two dyads - white donor to white recipient and white donor to black recipient-in the globe's foreign aid regime. ${ }^{33}$ Given the source of most aid flows and the race of many of the world's poorest persons, understanding the white-to-black dyad is surely of utmost importance. Yet the case of Africadescended recipients is perhaps a most likely instance to find a paternalistic-based generosity since, besides the recurring helpless-victim narrative presented by American media, the perceived threat to Americans of physical violence and economic competition from foreigners of African descent is rather minimal. In contrast, there are foreigners that many Americans do view with fear and resentment: Middle Eastern

\footnotetext{
${ }^{33}$ A lingering question is whether American whites' perceived differences in agency between foreign blacks and foreign whites arise from a somewhat inherent human tendency to dementalize out-groups or whether these differences are a product of how the U.S. media portrays Africans and Caribbeans. One way of getting leverage to answer this question would be to see if African-Americans exhibit the same pattern of behavior as the American white respondents analyzed above. If so, then it might suggest the presence of a generalized media construct rather than an in-group/out-group dynamic.The survey with the AG experiment did contain a sample of African-American respondents, but unfortunately their numbers are too low $(N=123)$ to arrive at a conclusive result. Among Africans-Americans, the treatment effect of Guyana $\times$ in-kind relative to Armenia $\times$ in-kind on support for foreign aid was positive (.34), as it was among whites, but not statistically significant ( $p=.154)$. Similarly, in Equation (1) of a mediation analysis, African-Americans downplayed the agentic capacities of Guyanese more than they did those of Armenians, but the result was nowhere near statistical significance $(p=.627)$. A more definitive conclusion will have to await larger nationally representative samples, oversamples of minorities, and/or analyses of multiple and different donor-recipient dyads (e.g., Prather 2014).
} 
Muslims (because of the perceived physical threat) and the Chinese (because of an alleged economic competition) come to mind (Wike and Grim 2010). Future research may reveal that Americans are less enthusiastic about aid to persons of East Asian or Middle Eastern descent than to those of African descent, and thereby lead to the conclusion that patterns of paternalism and resentment vary by recipient group or dyad.

At the same time, scholars of domestic economic redistribution (both in the U.S. and elsewhere) would be well-served to not ignore the possibility that paternalism as defined here, along with the resultant generosity toward an out-group, may exist in domestic contexts. Every now and then a scholar finds American whites to be more supportive of welfare to African-Americans than to compatriot whites (Pager and Freese 2006; Sniderman and Piazza 1993), yet thus far explanations for this unexpected finding have not been well-grounded theoretically. Scenarios in which a relatively poor group is largely segregated from the dominant group and poses minimal economic threat to it (e.g., the Roma in Europe) may also breed paternalistic-driven generosity among the dominant group.

It is important to clarify in closing that I am not arguing that feelings and behaviors of generosity toward Africa or the Caribbean are themselves inherently prejudicial. In other words, the assertion that racial paternalism drives the observed patterns in public opinion is not based solely on the race-of-recipient treatment effects. It is instead based on the role of paternalism in mediating and moderating the effect of race. Racial paternalism is behind the fact that respondents are more likely to believe that the foreign poor "are like extremely sick or paralyzed patients" when cued with black families than when cued with white ones. It is behind the fact that respondents are sensitive to how aid is delivered to Guyanese but not to Armenians. And it is behind the fact that the greater apparent generosity to countries with large African-descent population is wholly unrelated to the perception that they are poorer than Eastern European countries. If a sense that Africans are more deserving because they are poorer were at work, then perceptions of living standards would be closely related to foreign aid attitudes, but they are not. The prejudice-free, desirable middle ground between uncharitable resentment and charitable racial paternalism is a sentiment that involves compassion and generosity to the foreign poor regardless of their race, and, more importantly, one that treats them as active co-participants (e.g., via cash grants) in producing positive outcomes for themselves and their societies: "... the progress of humanitarianism cannot be achieved by humanitarians acting alone. Instead, it depends on creating a space for the objects of humanitarianism to express their own will to believe and the opportunity to act on those beliefs" (Barnett 2011, 239).

\section{REFERENCES}

Aguilar, Rosario, Saul Cunow, Scott Desposato, and Leonardo Barone. forthcoming. "Ballot Structure, Candidate
Race, and Vote Choice in Brazil." Latin American Research Review.

Alesina, Alberto, Reza Baqir, and William Easterly. 1999. "Public Goods and Ethnic Divisions." Quarterly Journal of Economics 114 (4): 1243-84.

Alesina, Alberto, Edward Glaeser, and Bruce Sacerdote. 2001. "Why Doesn't the United States Have a European-Style Welfare State?" Brookings Papers on Economic Activity 2 (Fall): 1-69.

Allport, Gordon. [1954] 1979. The Nature of Prejudice. Cambridge, MA: Perseus Books.

Ansolabehere, Stephen, and Douglas Rivers. 2013. "Cooperative Survey Research.” Annual Review of Political Science 16: 307-29.

Baker, Andy. 2009. The Market and the Masses in Latin America: Policy Reform and Consumption in Liberalizing Economies. New York: Cambridge University Press.

Banerjee, Abhijit V., and Esther Duflo. 2011. Poor Economics: A Radical Rethinking of the Way to Fight Global Poverty. New York: Public Affairs.

Banerjee, Abhijit V., Lakshmi Iyer, and Rohini Somanathan. 2005. "History, Social Divisions and Public Goods in Rural India." Journal of the European Economic Association 3 (2-3): 639-47.

Barnett, Michael. 2011. Empire of Humanity: A History of Humanitarianism. Ithaca, NY: Cornell University Press.

Benn, Julia, Andrew Rogerson, and Suzanne Steensen. 2010. Getting Closer to the Core: Measuring Country Programmable Aid. Paris: OECD.

Berinsky, Adam J. 2004. Silent Voices: Opinion Polls and Political Participation in America. Princeton: Princeton University Press.

Berinsky, Adam J. 2007. "Assuming the Costs of War: Events, Elites, and American Public Support for Military Conflict." Journal of Politics 69 (4): 975-97.

Berinsky, Adam J., and Tali Mendelberg. 2005. "The Indirect Effects of Discredited Stereotypes." American Journal of Political Science 49: 846-65.

Bermeo, Sarah Blodgett, and David Leblang. Forthcoming. "Foreign Interests: Immigration and the Political Economy of Foreign Aid." International Organization.

Blattman, Christopher, Nathan Fiala, Sebastian Martinez. 2014 "Generating Skilled Self-Employment in Developing Countries: Experimental Evidence from Uganda." Quarterly Journal of Economics 129 (2): 697-752.

Brader, Ted, Nicholas A. Valentino, and Elizabeth Suhay. 2008. "What Triggers Public Opposition to Immigration? Anxiety, Groups Cues, and Immigration Threat." American Journal of Political Science 52 (4): 959-78.

Brainard, Lael, and Vinca LaFleur. 2008. "Making Poverty History? How Activists, Philanthropists, and the Public are Changing Global Development." In Global Development 2.0: Can Philanthropists, the Public, and the Poor Make Poverty History? Lael Brainard and Derek Chollet, eds. Washington, DC: Brookings Institution Press, pp. 9-41.

Clawson, Rosalee A., and Rakuya Trice. 2000. "Poverty as We Know It: Media Portrayals of the Poor." Public Opinion Quarterly 64 (1) 53-64.

Cottrell, Catherine A., and Steven L. Neuberg. 2005. "Different Emotional Reactions to Different Groups: A Sociofunctional Threat-Based Approach to 'Prejudice'." Journal of Personality and Social Psychology 88 (5): 770-89.

Easterly, William. 2006. The White Man's Burden: Why the West's Efforts to Aid the Rest Have Done So Much Ill and So Little Good. New York: Penguin Press.

Fair, Jo Ellen. 1993. "War, Famine, and Poverty: Race in the Construction of Africa's Image." Journal of Communication Inquiry 17 (5): 5-22.

Feldman, Stanley, and Leonie Huddy. 2005. "Racial Resentment and White Opposition to Race-conscious Programs: Principles or Prejudice?" American Journal of Political Science 49 (1): 168-83.

Fiske, Susan T., Amy J. C. Cuddy, and Peter Glick. 2007. "Universal Dimension of Social Cognition: Warmth and Competence." Trends in Cognitive Science 11 (2): 77-83.

Fiske, Susan T., Amy J. C. Cuddy, Peter Glick, and Jun Xu. 2002. “A Model of (Often Mixed) Stereotype Content: Competence and Warmth Respectively Follow from Perceived Status and Competition." Journal of Personality and Social Psychology 82 (6): 878902 
Gaertner, Samuel, and John F. Dovidio. 1986. "The Aversive Form of Racism.” In John Dovidio and Samuel Gaertner, eds., Prejudice, Discrimination, and Racism. New York: Academic Press, pp. 6189.

Genovese, Eugene. 1974. Roll Jordan Roll: The World the Slaves Made. New York: Random House.

Gibson, Clark C., Krister Andersson, Elinor Ostrom, and Sujai Shivakumar. 2005. The Samaritan's Dilemma: The Political Economy of Development Aid. New York: Oxford University Press.

Gilens, Martin, 1996a. "'Race Coding' and White Opposition to Welfare." American Political Science Review 90 (3): 593-604.

Gilens, Martin, 1996b. "Race and Poverty in America: Public Misperceptions and the American News Media." Public Opinion Quarterly 60 (4): 515-41.

Gilens, Martin. 1999. Why Americans Hate Welfare. University of Chicago Press.

Gilens, Martin. 2001. "Political Ignorance and Collective Policy Preferences." American Political Science Review 95 (2): 379-96.

Gilliam, Franklin D., and Shanto Iyengar. 2000. "Prime Suspects: The Influence of Local Television News on the Viewing Public." American Political Science Review 44: 560-73.

Gray, Heather M., Kurt Gray, and Daniel M. Wegner. 2007. "Dimension of Mind Perception." Science 315: 619.

Gray, Kurt, Joshua Knobe, Mark Sheskin, Paul Bloom, and Lisa Feldman Barret. 2011. "More than a Body: Mind Perception and the Nature of Objectification." Journal of Personality and Social Psychology 101 (6): 1207-20.

Griffin, John D., and Brian Newman. 2008. Minority Report: Evaluating Political Equality in America. Chicago: University of Chicago Press.

Habyarimana, James, Macartan Humphreys, Daniel N. Posner, and Jeremy M. Weinstein. 2009. Coethnicity: Diversity and the Dilemmas of Collective Action. New York: Russell Sage Foundation.

Hancock, Ange-Marie. 2004. The Politics of Disgust: The Public Identity of the Welfare Queen. New York: New York University Press.

Hartz, Louis. 1955. The Liberal Tradition in America: An Interpretation of American Political Thought since the Revolution. New York: Harcourt.

Hawk, Beverly, ed. 1992. Africa’s Media Image. New York: Praeger.

Hegel, Georg Wilhelm Friedrich. [1837] 2007. The Philosophy of History. New York: Cosimo Books.

Holsti, Ole R. 2004. Public Opinion and American Foreign Policy. Ann Arbor: University of Michigan Press.

Imai, Kosuke, Luke Keele, Dustin Tingley, and Teppei Yamamoto. 2011. "Unpacking the Black Box of Causality: Learning about Causal Mechanism from Experimental and Observational Studies." American Political Science Review 105 (4): 765 89.

Imai, Kosuke, Gary King, and Elizabeth Stuart. 2008. "Misunderstandings among Experimentalists and Observationalists about Causal Inference.” Journal of the Royal Statistical Society 171 (2): 481-502.

Iyengar, Shanto. 1990. "Framing Responsibility for Political Issues: The Case of Poverty." Political Behavior 12 (1): 19-40

Jackman, Mary R. 1994. The Velvet Glove: Paternalism and Conflict in Gender, Class, and Race Relations. Berkeley, California: University of California Press.

Jacobs, Lawrence R., and Benjamin I. Page. 2005. "Who Influences U.S. Foreign Policy?" American Political Science Review 99 (1): $107-23$.

Joy, Charles R. 1947. Albert Schweitzer: An Anthology. Boston: Beacon Press.

Katz, Irwin, and R. Glen Hass. 1988. "Racial Ambivalence and American Value Conflict: Correlational and Priming Studies of Dual Cognitive Structures." Journal of Personality and Social Psychology 55 (6): 893-905.

Kharas, Homi. 2008. "The New Reality of Aid." In Global Development 2.0: Can Philanthropists, the Public, and the Poor Make Poverty History? Lael Brainard and Derek Chollet, eds. Washington, DC: Brookings Institution Press, pp. 53-73.

Kinder, Donald R., and Cindy D. Kam. 2009. Us against Them: Ethnocentric Foundations of American Opinion. Chicago: University of Chicago Press.
Kinder, Donald R., and Lynn M. Sanders. 1996. Divided by Color: Racial Politics and Democratic Ideals. Chicago: University of Chicago Press.

King, Gary, James Honaker, Anne Joseph, and Kenneth Scheve. 2001. "Analyzing Incomplete Political Science Data: An Alternative Algorithm for Multiple Imputation." American Political Science Review 95 (1): 49-69.

Kozak, Megan N., Abigail A. Marsh, and Daniel M. Wegner. 2006. "What Do I Think You're Doing? Action Identification and Mind Attribution." Journal of Personality and Social Psychology 90 (4): 543-55.

Krosnick, Jon A., Allyson L. Holbrook, Matthew K. Berent, Richard T. Carson, W. Michael Hanemann, Raymond J. Kopp, Robert Cameron Mitchell, Stanley Presser, Paul A. Ruud, V. Kerry Smith, Wendy R. Moody, Melanie C. Green, and Michael Conaway. 2002. "The Impact of 'No Opinion' Response Options on Data Quality: Non-attitude Reduction or an Invitation to Satisfice? Public Opinion Quarterly 66: 371-403.

Leyens, Jacques-Philippe, Paola M. Paladino, Ramon RodriquezTorres, Jeroen Vaes, Stéphanie Demoulin, Armando RodriguezPerez, and Ruth Gaunt. 2000. "The Emotional Side of Prejudice: The Attribution of Secondary Emotions to Ingroups and Outgroups." Personality and Social Psychology Review 4 (2): 18697.

Malle, Betram F., and Gale E. Pearce. 2001. "Attention to Behavioral Events during Interaction: Two Actor-Observer Gaps and Three Attempts to Close Them." Journal of Personality and Social Psychology 81 (2): 278-94.

Mamdani, Mahmood. 1996. Citizen and Subject: Contemporary Africa and the Legacy of Late Colonialism. Princeton: Princeton University Press.

Mamdani, Mahmood. 2009. Saviors and Survivors: Darfur, Politics, and the War on Terror. New York: Random House.

Mendelberg, Tali. 2001. The Race Card: Campaign Strategy, Implicit Messages, and the Norm of Equality. Princeton: Princeton University Press.

Milner, Helen V., and Dustin H. Tingley. 2013a. "The Choice for Multilateralism: Foreign Aid and American Foreign Policy." Review of International Organizations 8 (3): 313-41.

Milner, Helen V., and Dustin H. Tingley. 2013b. "Public Opinion and Foreign Aid: A Review Essay." International Interactions 39 (3): 389-401.

Moyo, Dambisa. 2009. Dead Aid: Why Aid is Not Working and How There is a Better Way for Africa. New York: Farrar, Straus, and Giroux.

Mutz, Diana C. 2011. Population-Based Survey Experiments. Princeton: Princeton University Press.

Pager, Devah, and Jeremy Freese. 2006. "Safety Net for Whom? Race, Assessments of Culpability, and Attitudes about Public Assistance for the Unemployed." Paper presented at the annual meeting of the American Sociological Association, Montreal Convention Center, Montreal, Quebec, Canada.

Paxton, Pamela and Stephen Knack. 2012. "Individual and Country Level Factors Affecting Support for Foreign Aid." International Political Science Review 33: 150-70.

Prather, Lauren. 2014. "Transnational Ties and Support for International Redistribution." Paper presented at the Annual Comparative Approaches to the Study of Immigration, Ethnicity, and Religion Workshop.

Sachs, Jeffrey. 2005. The End of Poverty: Economic Possibilities for Our Time. New York: Penguin Press.

Scott, Daryl Michael. 1997. Contempt and Pity: Social Policy and the Image of the Damaged Black Psyche, 1880-1996. Chapel Hill, NC: University of North Carolina Press.

Seay, Laura. 2012. "How Not to Write about Africa." Foreign Policy April 25, 2012.

Sniderman, Paul M., and Thomas Piazza. 1993. The Scar of Race. Cambridge, MA: Harvard University Press.

Soss, Joe, Richard C. Fording, and Sanford F. Schramm. 2011. Disciplining the Poor: Neoliberal Paternalism and the Persistent Power of Race. Chicago: University of Chicago Press.

Thaler, Richard H., and Cass R. Sunstein. 2008. Nudge: Improving Decisions about Health, Wealth, and Happiness. New York: Penguin Books. 
Tomz, Michael R., and Jessica L. P. Weeks. 2013. "Public Opinion and the Democratic Peace." American Political Science Review 107 (4): 849-65.

Vandeveer, Donald. 1986. Paternalistic Intervention: The Moral Bounds of Benevolence. Princeton University Press.

van Heerde, Jennifer, and David Hudson. 2010. "The Righteous Considereth the Cause of the Poor'? Public Attitudes towards Poverty in Developing Countries." Political Studies 58 (3), 389409.

Wainaina, Binyavanga. 2005. "How to Write about Africa." Granta 92 (Winter): 91-5.

Waytz, Adam, Kurt Gray, Nicholas Epley, and Daniel M. Wegner. 2010. "Causes and Consequences of Mind Perception." Trends in Cognitive Sciences 14: 383-8.
Weiner, Bernard. 1993. "On Sin versus Sickness: A Theory of Perceived Responsibility and Social Motivation." American Psychologist 48 (9): 957-65.

Wike, Richard, and Brian J. Grim. 2010. "Western Views toward Muslims: Evidence from a 2006 Cross-National Survey." International Journal of Public Opinion Research 22 (1): 4-25.

Winter, Nicholas J. G. 2008. Dangerous Frames: How Ideas about Race and Gender Shape Public Opinion. Chicago: University of Chicago Press.

Zucco Jr., Cesar. 2014. "Conditionality and Support for Redistributive Transfers: Results from Observational and Survey Experimental Studies." Presented at the Annual Meeting of the American Political Science Association, Washington, DC. 